\title{
Natural Resources Dependency: Are Indigenous Communities Ready to Switch to New Career?
}

\author{
KHATIJAH OMAR ${ }^{1}$, SITI NOR ADAWIYAH AZZAHRA KAMARUDDIN ${ }^{2}$, MD KHAIRUL AZWAN MD \\ RAZALI ${ }^{3}$, NORHAYATI AB MANAF ${ }^{4}$, MOHAMMAD ABI SOFIAN ABDUL HALIM ${ }^{5}$, \\ NORHAYATI SA'AT ${ }^{6}$ \\ ${ }^{1}$ Institute of Biodiversity Tropical and Sustainable Development \& Faculty of Business, Economics, and Social \\ Development, UNIVERSITI MALAYSIA TERENGGANU, MALAYSIA. E-mail: khatijah@umt.edu.my \\ ${ }^{2}$ Faculty of Business, Economics, and Social Development, UNIVERSITI MALAYSIA TERENGGANU, MALAYSIA. \\ E-mail: azzahrakamaruddin@gmail.com \\ ${ }^{3}$ Institute of Biodiversity Tropical and Sustainable Development, UNIVERSITI MALAYSIA TERENGGANU \\ MALAYSIA.E-mail:md.khairular@gmail.com \\ ${ }^{4}$ Institute of Biodiversity Tropical and Sustainable Development, UNIVERSITI MALAYSIA TERENGGANU, \\ MALAYSIA. E-mail: yati.manaf@umt.edu.my \\ ${ }^{5}$ Institute of Biodiversity Tropical and Sustainable Development \& Faculty of Business, Economics, and Social \\ Development, UNIVERSITI MALAYSIA TERENGGANU, MALAYSIA. E-mail: abi.sofian@umt.edu.my \\ ${ }^{6}$ Institute of Biodiversity Tropical and Sustainable Development \& Faculty of Business, Economics, and Social \\ Development, UNIVERSITI MALAYSIA TERENGGANU, MALAYSIA. E-mail: norhayati@umt.edu.my
}

\begin{abstract}
Indigenous community or better known as Orang Asli community in Malaysia, like most indigenous communities in other parts of the world, are found to still depend very much on natural resources as the main source for their livings. They too are the group of peoples that hardly welcome development activities that can bring harm to the environment. This study was conducted with the objective to investigate the dependency on natural resources among the Orang Asli at Sungai Sayap, Besut, Terengganu and their readiness to switch to other careers, other than farming and hunting. A total of 20 adult participants from this small Orang Asli village were involved in this study. The data for descriptive analysis (percentage) was analyzed using the Statistical Package for Social Science (SPSS Version 20). The findings of the study show that 50 percent of Orang Asli at Sungai Sayap, Terengganu still rely on the resources from the forest around them for their economic and social benefits. However, realizing the fact that natural resources are depleting, 75 percent of the respondents are ready to switch to new careers. The findings can give initial overview to the agencies that involve with indigenous people or Orang Asli, to plan and provide training programs that can be offered to indigenous people to ensure that they can adapt and stay put in their new career. The research will benefit the state government, institutions as well as indigenous community so as to promote sustainable development among marginalized community.
\end{abstract}

Keywords: Natural Resources, Indigenous People, Sustainable Livelihood, New Career, Sungai Sayap Terengganu JEL Classification: J15 


\section{Introduction}

Indigenous community is one of the communities that makes up the total of population in Malaysia and majority of this community still depends on the nature around them. They still depend on traditional farming, collecting forest products and hunting animals to meet their daily life needs. Most of these indigenous people live in forests and it is common that their houses are made from natural resources such as wood, rattan and shrubbery. Indigenous people and the environment can be said to be inseparable because according to their ancestors' beliefs, their lives are related to the spirit of the elements of the environment. In fact, the indigenous communities are very sensitive to the environment around them. Nonetheless, the indigenous communities care very much about the environment around them. They will make sure that they use the natural resources wisely and when they build their huts or houses in the forest, they do it without harming the environment.

\section{Literature Review}

\subsection{Community of Indigenous People}

It is estimated that there are more than 370 million of indigenous people in 70 countries around the world and two-thirds of them live in Asian countries (Champion, 2010; UNDP, 2012). In Malaysia, indigenous communities are among the minority communities and they are scattered around in the Peninsular Malaysia, Sabah and Sarawak. In Malaysia, indigenous people are known as Orang Asli. According to Jamiran, Seow and Mohamed (2013), the Orang Asli community in Malaysia is among the communities that still preserve their unique culture and heritage that is inherited from their ancestors. Therefore, it is not surprising if some of the Orang Asli settlements have become tourist attractions for those who are interested and value their culture, heritage and lifestyle.

According to Yusof, Roddin and Warman, (2017), the Orang Asli in Peninsular Malaysia are divided into three sub-groups, namely Senoi, Negrito and Proto-Malay. Sam (2015) stated that the Senoi ethnic of Orang Asli is the largest group in Peninsular Malaysia followed by Proto-Malays and Negritos. In addition, each of these main ethnic groups are further divided into six sub-ethnic groups, making it a total of 18 indigenous sub-ethnic groups, as shown in Table 1. Sron, MaMasami and Ismail (2013) stated that indigenous peoples are not from a homogeneous group because each ethnic group has different languages and cultures and they consider themselves to be different from other ethnic groups. In Malaysia, all matters related to indigenous people are under the jurisdiction of the Department of Indigenous Affairs (JAKOA).

Table 1 Sub-Ethnic Groups of Orang Asli in Peninsular Malaysia.

\begin{tabular}{|c|c|c|}
\hline Senoi & Melayu-Proto & Negrito \\
\hline Semai & Temuan & Kensiu \\
\hline Temiar & Semelai & Kintak \\
\hline Jahut & Jakun & Jahai \\
\hline Che' Wong & Orang Kanaq & Lanoh \\
\hline Mah Meri & Orang Kuala & Mendriq \\
\hline Semoq Beri & Orang Seletar & Bateq \\
\hline
\end{tabular}

Source: Harun, Wai, Othman, Yusoff \& Ramli, 2011

Orang Asli people from Senoi ethnic is the largest community representing $54 \%$ of the total population of Orang Asli in Peninsular Malaysia, while the group of Proto-Malays and Negritos each made up of $43 \%$ and $3 \%$ of the total (JHEOA, 2003; Nicholas, 2000). Furthermore, Carey (1976) states that the smallest indigenous group, Negrito, is one of the earliest groups to set up settlements in Peninsular Malaysia, that was about 25,000 years ago. 
In 2003 there were 147,412 Orang Asli registered throughout Peninsular Malaysia (Suhakam ,2013). Meanwhile, in 2018, data updated by the Jabatan Kemajuan Orang Asli (JAKOA) revealed that the number had increased to 178,197 (JAKOA, 2018). JAKOA (2014) also reported that there are 853 Orang Asli settlement villages inhabited by various Orang Asli groups in the state of Pahang, Perak, Selangor, Kelantan, Johor, Negeri Sembilan, Melaka, Terengganu and Kedah (Table 2). Most of the Orang Asli settlements are concentrated in the suburbs ( 525 villages) while 322 villages are in the rural areas and six in urban areas (Abdullah et al., 2016). Nonetheless, the Orang Asli community represents less than $1 \%$ of 29 million of Malaysian population.

Table 2 Number of Villages and Community Orang Asli by States

\begin{tabular}{|c|c|c|}
\hline States & Number of Villages & Number of Communities \\
\hline Pahang & 262 & 67,506 \\
\hline Perak & 255 & 53,299 \\
\hline Selangor & 74 & 17,587 \\
\hline Kelantan & 118 & 13,457 \\
\hline Johor & 58 & 13,139 \\
\hline Negeri Sembilan & 68 & 10,531 \\
\hline Melaka & 14 & 1,515 \\
\hline Terengganu & 3 & 893 \\
\hline Kedah & 1 & 270 \\
\hline Total & 853 & 178,197 \\
\hline
\end{tabular}

Source: JAKOA, 2014; JAKOA, 2018

The current study aimed to determine whether the indigenous people in Terengganu are dependent on natural resources, especially involving indigenous people in $\mathrm{Kg}$. Sungai Sayap, Terengganu. Kg. Sungai Sayap is also one of the villages in the state of Terengganu in Peninsular Malaysia that is a home to indigenous people. In Terengganu there are 3 villages that are inhabited by Orang Asli, which are Kg. Sungai Berua in Hulu Terengganu, Kg.Sungai Sayap in Setiu and Kg. Sg. Pergam in Kemaman. According to JAKOA $(2018$,$) to date there are 893$ indigenous people living in those three villages. The Orang Asli community in Terengganu is made up of the sub-ethnic groups of Semaq Beri, Jakun, Bateq, Che' Wong and Semai. Majority of the Orang Asli who reside in Kg. Sungai Berua and Kg. Pergam is from a sub-ethnic Semaq Beri, while majority of Orang Asli who live in Kg. Sungai Sayap is from the Bateq ethnic group. Orang Asli people in Kg. Sungai Sayap mostly live-in brick houses provided by the government.

Table 3 Number of Orang Asli by Ethnic in Terengganu

\begin{tabular}{|c|c|c|}
\hline Ethnic & Sub-Ethnic & Number of Community \\
\hline Negrito & Bateq & 34 \\
\hline \multirow{2}{*}{ Senoi } & Semai & 3 \\
\cline { 2 - 3 } & Semaq Beri & 811 \\
\cline { 2 - 3 } & Che' Wong & 4 \\
\hline \multirow{2}{*}{ Melayu-Proto } & Temuan & 1 \\
\cline { 2 - 3 } & Jakun & 40 \\
\hline Total & & 893 \\
\hline
\end{tabular}

Source: JAKOA, 2018

The lifestyle of indigenous people (Orang Asli) in Terengganu is similar to that of other indigenous people in other countries. Traditionally, their lives are closely linked to nature such as forests, hills, mountains and rivers that lead them to nomadic lifestyle. In fact, most of their daily basic needs, social and economic activities are related to nature and natural resources. 


\subsection{The Dependency on Natural Resources}

Dependency on natural resources by indigenous people is something that is indeed indisputable and unquestionable. This is because they are the communities living in the jungle and practicing primitive ways of lifestyle. Accordingly, it is not surprising that the indigenous people have also been given the title of 'Forest People' by some researchers or scholars. The term also coincides with the meaning of the term 'Semaq Beri' itself which means 'jungle' (Abdul Rahman, 2018).

According to Abdul Rahman (2018), some of the Negrito groups still practice their traditionally nomadic lifestyle. This greatly affects their socio-economic status because they are those who prefer to hunt animals in the forest, catch fish in the rivers and seas and gather forest produce rather than involving in agriculture whether in short term or long term. In contrast, Senoi Proto-Malays are slightly advanced because they are no longer nomadic but more involved in agricultural activities such as growing paddy, rubber trees as well as fruit trees. However, Gomes (2004) stated that Orang Asli Senoi are also different from Proto-Malay. The Senoi practices subsistence farming activties and also shifting agriculture.

Natural resources are an extremely important to indigenous peoples' life since they depend very much on forest produce to ensure their survival. That is why they really appreciate nature and if they use natural resources, they use them wisely and not in excessive manner (Ramlee et al., 2014) to ensure their survival. They help to conserve and sustain their natural resources for future generations to inherit (Abdullah et al., 2020; Hood et al., 2009; Khan \& Qureshi, 2020).

To indigenous peoples, nature is not only rich with resources, but also posseses mysterious power that can influence their daily activities and how they lead their life (Chunhabunyatip et al., 2018, Alejandro Fuentes, 2017)). According to Muhammad Syamsul et al. (2016), the relationship between indigenous peoples and forests is very close as if the forest is also like human beings, and they treat forests with respect. Redzuan and Emby (2008) also wrote that forests have a profound effect on indigenous peoples' life. All the knowledge and skills used for their survival in the forests, they get them because of their strong bond with nature. In fact, forest and natural environment have influenced their beliefs, practices and way of life (Maharam, 2009).

Hunting and collecting forest products have been the career of Orang Asli since long time ago. Men will go into the forest for hunting and getting fruits, vegetables and herbs to support their families. Abdullah et al. (2016) stated that men who go into the forest usually from early morning until late in the evening and sometimes they also go into the forest for a relatively long period of time up to a week to collect forest produces. In certain cases, the forest products that they get, they will sell them to outsiders. Candyrilla et al., (2016) reported that Orang Asli can earn up to RM300-RM500 from the sale of the forest products like rattan and bamboos that they collect in two weeks. Sometime they can also earn up to RM800-RM3000 for the sale of valuable timber for a two-week working period.

The study by Er et al. (2010) found that Orang Asli community in the Bukit Lagong Forest Reserve are self-sustaining in that they rely on forest resources to generate income. They involve in activities such as farming, collecting forest produce, tapping rubber and weaving rattan, bamboo and roots. However, recently some of them have also grabbed career opportunities in the public and private sectors. Similarly, Orang Asli community in Ulu Tual, Kuala Lipis, Pahang, even though most of them are still dependent on natural resources, some of them have moved on to other careers besides collecting forest produce and hunting. In fact, they are willing to be involved in challenging careers if they are given trainings (Omar et al., 2018).

In actual fact, indigenous people are not blindly rejecting any development activities, but they are only concerned with the principles of development that respect their rights and their efforts to protect the forests and nature. According to Carol (2008), resistance to development among the indigenous people usually occur in the event of forest encroachment of which they bring adverse consequences such as damage to the river which is a major source of their survival. In general, these minority community is also looking forward for development and progress for a more comfortable lifestyle. 
Resistance to development among Orang Asli is only a claim to the preservation of nature and not a rejection towards development in total (Maharam, 2009).

\section{Methodology/Materials}

Data for this study were collected from 20 Orang Asli respondents living in Sg. Sayap Village, Terengganu, Malaysia. This village is a small village of Orang Asli with only 14 houses altogether. This village was chosen for the study since this village is inhibited by indigenous people but other villages surrounding this village are inhibited by locals who practice modern way of life. Simple questionnaires were used to obtain information from them. During the data collection process, the help from Tok Batin (the leader of the village) who is very fluent in Malay was obtained to explain the meaning of some statements in the questionnaires. The data obtained were analyzed using descriptive analysis.

\section{Results and Findings}

Table 4 Descriptive Analysis (Respondent Profile)

\begin{tabular}{|c|c|c|c|}
\hline \multicolumn{2}{|c|}{ Characteristics } & \multirow{2}{*}{$\frac{\text { Frequency }(\mathrm{n}=20)}{4}$} & \multirow{2}{*}{$\begin{array}{c}\text { Percentage } \\
20\end{array}$} \\
\hline & Male & & \\
\hline 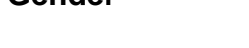 & Female & 16 & 80 \\
\hline \multirow{14}{*}{ Age } & 23 Year & 1 & 5 \\
\hline & 15 Year & 1 & 5 \\
\hline & 30 Year & 1 & 5 \\
\hline & 39 Year & 1 & 5 \\
\hline & 45 Year & 2 & 10 \\
\hline & 62 Year & 2 & 10 \\
\hline & 31 Year & 2 & 10 \\
\hline & 21 Year & 2 & 10 \\
\hline & 58 Year & 1 & 5 \\
\hline & 32 Year & 2 & 10 \\
\hline & 26 Year & 2 & 10 \\
\hline & 29 Year & 1 & 5 \\
\hline & 28 Year & 1 & 5 \\
\hline & 35 Year & 1 & 5 \\
\hline \multirow{2}{*}{ Ethnic } & Bateq & 19 & 95 \\
\hline & Malay & 1 & 5 \\
\hline \multirow{3}{*}{ Marital Status } & Single & 6 & 30 \\
\hline & Married & 12 & 60 \\
\hline & Single Mother & 2 & 10 \\
\hline \multirow{3}{*}{ Education level } & Not completing School & 11 & 55 \\
\hline & Primary School (UPSR) & 4 & 20 \\
\hline & Secondary School (SRP/PMR) & 3 & 15 \\
\hline \multirow{2}{*}{ Occupation } & Farmer/fishers & 16 & 80 \\
\hline & Others & 4 & 20 \\
\hline Income Level & Less than RM999 & 20 & 100 \\
\hline Location & Sungai Sayap & 20 & 100 \\
\hline
\end{tabular}


Table 4 shows that the respondents of Orang Asli involved in this study were $80 \%$ female (16) and only $20 \%$ male (4). The age of the respondents in this study was ranged between 15 and 62 years old. Most of them were from the Bateq tribe which is 95 per cent and 5 per cent Malays. The majority of respondents were married $(60 \%)$, single $(30 \%)$ and single mothers were $10 \%$.

Most of the respondents who involved in this study did not complete their study at primary school level (55\%). In terms of occupation, most of them work as farmers or fish catchers. In terms of income earned per month, all of them (100\%) earn less than RM999 per month.

Table 5 reveals that 50 percent of Orang Asli still depend on forest resources and 50 percent of Orang Asli in Sg Sayap said that they no longer use or rely on forest resources. However, it is believed that those who said that they do not use the forest resources, maybe because they did not really understand the question or they misunderstood the question. Among the natural resources they obtain from the jungle are ginseng, Tongkat Ali, Kacip Fatimah, pine, rattan, and even roots of certain valuable medicinal herbs. When asked the next question, whether they use the forest resource for personal use, sale or both for personal use and sale, $15 \%$ said they use forest resources for personal use, $30 \%$ said for sale and $55 \%$ said they use the resources both for personal use and sale. Usually, if they use the forest resources for their personal use, they use them as medicine, food, decorative items or handicrafts. For the resources that they sell to outsiders, the prices of the items range from RM30 to RM200, depending on the value of the items.

Table 5 also shows that $75 \%$ of the Orang Asli in Sg. Sayap are willing to switch to new job or new career if the natural resources surrounding them are depleting. Only $25 \%$ of the Orang Asli in Sg Sayap are still reluctant to change to new careers. Among the careers that they would like to pursue if they are given the opportunity are farming, housekeeping, bakery and chef. It is not surprising if farming is still their number one choice since farming is very closely associated with environment and natural resources.

Table 5 Descriptive Analysis (Percentage)

\begin{tabular}{|c|c|c|c|}
\hline \multicolumn{2}{|c|}{ Items } & Frequency(n=20) & Percentage \\
\hline Do you use the resources of the forest around your \\
village? & Yes & 10 & 50 \\
\cline { 2 - 4 } Is it for personal use or for sale? & No & 10 & 50 \\
\hline & Personal use & 3 & 15 \\
\cline { 2 - 4 } & Sale & 6 & 30 \\
\cline { 2 - 4 } & Both & 11 & 55 \\
\hline Are you ready for farming, rearing, or involved with other \\
work if the natural resource becoming lesser? & Yes & 15 & 25 \\
\cline { 2 - 4 } & No & 5 & 25 \\
\cline { 2 - 4 } If given opportunity to work, what job is your choice? & Farming & 5 & 5 \\
\cline { 2 - 4 } & Carpenter & 1 & 50 \\
\cline { 2 - 4 } & Not Sure & 10 & 15 \\
\cline { 2 - 4 } & Bakers & 3 & 5 \\
\hline
\end{tabular}

\section{Conclusion}

Indigenous peoples are inseparable from natural resources and environment. Ever since, they have relied heavily on natural resources to survive their lives. The same goes to indigenous people (Orang Asli) in Sg. Sayap, Setiu, Terengganu who also still depend on the natural resources available around their settlements for their daily use and also as a source of their income. Therefore, they care for their environment and they try to make every effort to protect their nature and forest resources from being damaged especially by development activities. They are very worried if there is development in the area around them because it will damage the nature in their area and this will certainly affect the sustainability of their lives. However, development activities from day to day cannot be put into a stop. Recognizing the fact that natural resources are facing the threat of destruction and depletion, the Orang Asli people in Sg. Sayap, in general, are ready to switch their careers; from traditional farmers, hunters and forest produce collectors to new careers like modern farmers, carpenters and others. However, to ensure that the Orang Asli community is able to adapt and stay put with their new career 
in future, the relevant parties must provide appropriate trainings to Orang Asli communities. Since these indigenous people are also interested in becoming farmers, special training on farming must also be provided. Besides that, some policy reforms that relate to indigenous people in Malaysia are required, such as policies that relate to employment opportunity so that these indigenous people (Orang Asli) can enjoy fair employment opportunity and they will not be left behind. Realizing that natural resources gradually depleting, land zoning plans and confirmation of indigenous people's earlier land ownership should be prepared for the areas that these Orang Asli inhibit to ensure that they can actively involve in farming without any regulatory disruption in future.

\section{Limitations of the Study}

Sungai Sayap village is among the three villages that are inhibited by indigenous people in Terengganu, Malaysia. Since this village is only a small village, the number of the population as well as the sample is also small and this limits the generalizability of the results. Besides, the questions asked in this research are in Malay language. Even though the help from Tok Batin (the leader of the village) who is very fluent in Malay was sought to explain the meaning of some statements in the questionnaires, this is also a limitation since respondents themselves might misunderstood the questions.

\section{Future Research}

The future research can take into consideration a larger population and a larger sample size to study because a large sample size is more representative. Besides, a large sample size forms a better picture for analysis.

\section{Acknowledgments}

The authors would like to thank Universiti Malaysia Terengganu for funding this research under Knowledge and Technology Assimilation Grant (KTAG).

\section{References}

1. Abdullah, M. F., Othman, A., Jani, R., Bartholomew, C. V., Pesiu, E., \& Abdullah, M. T. (2020). Traditional Knowledge and the Uses of Natural Resources by the Resettlement of Indigenous People in Malaysia. Journal of Southeast Asian Studies, 25(1), 168-190.

2. Abdullah, M. T., Abdullah, M. F., Bartholomew, C. V., \& Jani, R. (2016). Kelestarian Orang Asli Terengganu. Kuala Terengganu: Penerbit Universiti Malaysia Terengganu.

3. Abdul Rahman, H. (2018). World View Masyarakat Orang Asli Dan Pelestarian Alam Sekitar. Prosiding Seminar Antarabangsa Arkeologi, Sejarah, Bahasa dan Budaya di Alam melayu (ASBAM) ke-7, Hotel Jayakarta, Lombok, Nuisa Tenggara, Indonesia, 28-29 Julai 2018, 375-789.

4. Alejandro, F. (2017). Protection of Indigenous Peoples' Traditional Lands and Exploitation of Natural Resources: The Inter-American Court of Human Rights' Safeguards. International Journal on Minority and Group Rights, 24, 229-253.

5. Candyrilla, V. B., Muhammad Syamsul A. A., \& Abdullah, M. T. (2016). Orang Asli dan Sumber Alam. in Abdullah, M. T., Muhammad Fuad, A., Candyrilla V, B., dan Rohana, J. (Eds.). Kelestarian Orang Asli Terengganu. Kuala Terengganu: Penerbit Universiti Malaysia Terengganu. 45-70.

6. Carey, I. (1976). Orang Asli: The Aboriginal Tribes Of Peninsular Malaysia. New York: Oxford University Press.

7. Carol, Y. O. L. (trans). (2008). Tanah Menyara Hidup: Hak-hak Tanah dan Pengembangan Perladangan Kelapa Sawit di Sarawak. Marcus Colchester, Wee Aik Pang, Wong Meng Chuo and Thomas Jalong. n.p.: Forest Peoples Programme and Perkumpulan Sawit Watch. 
8. Chunhabunyatip, P., Sasaki, N., Grünbühel, C., Kuwornu, J. K. M., \& Tsusaka, T. W. (2018). "Influence of Indigenous Spiritual Beliefs on Natural Resource Management and Ecological Conservation in Thailand" Sustainability 10, no. 8: 2842. https://doi.org/10.3390/su10082842.

9. Er, A. C., Che Mat Arrifin, Z., \& Pereira, J. (2010). Sosioekonomi Masyarakat Orang Asli Kajian Kes di Hutan Simpan Bukit Lagong, Selangor, Malaysia. Jurnal Melayu, 5, 295-314.

10.Gomes, A.G. (2004). Orang Asli in Malaysia. International Institute for Asian Studies Newslatter, 35:10.

11.Harun, R., Wai, Y. H., Othman, F., Yusoff, M. K., \& Ramli, M. F. (2011). Kepelbagaian Biologi dan Nilai Hutan untuk Kelangsungan Hidup Orang Asli Kajian Kes di Taman Negara Royal Belum. in Rahim, A. R. A., Koh, H. L, Abdullah, M., Latiff, A. (Ed). Taman Negara DiRaja Belum, Perak. Pengurusan Hutan, Persekitaran Fizikal, Kepelbagaian Biologi dan Sosioekonomi. Kuala Lumpur: Jabatan Perhutanan Semenanjung Malaysia. ms. 322- 332.

12.Hood, S., Ruzy, S. H, Christof, J., Joerg, C., \& Zurinawati, Z., A. (2009). Health and Beauty from the Rainforest. Singapura: Editions Didier Millet.

13.Jabatan Kemajuan Orang Asli Malaysia (JAKOA). (2014). Retrieved from http://www.rurallink.gov.my/wp-content/uploads/2015/05/7-JAKOA.pdf.

14.Jabatan Kemajuan Orang Asli Malaysia (JAKOA). (2016). Retrieved from http://www.data.gov.my/data/ms_MY/dataset/4b59c909-df99-41b6-884f-

d8c5bf1719e5/resource/4b5e9926-436d-4111-84f9ea8b92474c31/download/pendudukoasubetnikmac-2018.xlsxl.

15.Jamiran, S., Seow, T. W., \& Mohamed, M. (2013). Pembangunan Sosioekonomi Komuniti Orang Asli di Malaysia. Retrieved from http://eprints.uthm.edu.my/3997/1/PEMBANGUNAN_SOSIOEKONOMI_KOMUNITI_OR ANG_ASLI.pdf.

16.Jaura, R. (2010). Of Indigenous Peoples, Climate Change and Rural Poverty. Retrieved from Development Watch An Alliance for Monitoring International Cooperation: http://www.developmentwatch.net/index.php?option=com_content\&view=article\&id=39:ofindigenous-peoples-climate-change-and-rural-poverty\&catid=1: news\&Itemid=5.

17.Khan, N., \& Qureshi, M. I. (2020). A systematic literature review on online medical services in Malaysia. International Journal of Online and Biomedical Engineering, 16(6), 107-118. https://doi.org/10.3991/ijoe.v16i06.13573

18. Maharam, M. (2009). Interaksi Masyarakat Peribumi dan Alam Sekitar: Satu Kajian Etika Dalam Novel Jong Chian Lai. Paper dibentangkan di Simposium Kebudayaan Indonesia-Malaysia (SKIMIX), Universitas Padjajaran, Bandung, Indonesia.

19. Muhammad Syamsul, A. A., Candyrilla, V. B., \& Abdullah, M. T. (2016). Keterancaman dan Kelestarian Kehidupan Masyarakat Orang Asli. in. Mohd Tajuddin Abdullah, Muhammad Fuad Abdullah, Candyrilla Vera Bartholomew \& Rohana Jani (Eds.). Kelestarian Orang Asli Terengganu. Kuala Terengganu: Penerbit Universiti Malaysia Terengganu.71-84.

20.Nicholas, C. (2000). The Orang Asli and the Contest for Resources: Indigenous Politics, Development and Identity in Peninsular Malaysia . Subang Jaya: Centre for Orang Asli Concerns.

21.Omar, K., Abdul Halim, M. A., \& Samsudin, H. (2018, December). Career Transformation among Orang Asli: Are They Ready? Indian Journal of Public Health Research \& Development, 9(12), 26152619. 
22.Österlin, C., \& Raitio, K. (2020). "Fragmented Landscapes and Planscapes-The Double Pressure of Increasing Natural Resource Exploitation on Indigenous Sámi Lands in Northern Sweden" Resources 9 (9),104.

23.Ramle, A. Asmawi, I., Mohamad Hafis, A. S., Nur Hafizah, R., \& Mohd Sukhairi, M. R. (2014). Pemuliharaan Hutan dalam Kalangan Semaq Beri di Negeri Terengganu, Malaysia. Malaysia Journal of Society and Spaces, 10: 113-124.

24.Redzuan, M., \& Emby, Z. (2008). Orang Asli: Pembangunan dan Ekologi Hutan. DIm. Marof Redzuan dan Sarjit S. Gill (Pnyt.). Orang Asli: Isu, Transformasi dan Cabaran. Serdang: Penerbit Universiti Putra Malaysia.

25.Sam, S. A. (2015). Kajian Amalan Budaya Orang Asli Suku Kaum Jakun di Kampung Peta.

26.Sron, T., MaMasami, F., \& Ismail, N. (2013). Orang Asli in Peninsular Malaysia : Population, Spatial Distribution and Socio-Economic Condition. Ritsumeikan Journal of Social Sciences and Humanities, 6, 75-115. Retrieved from http://www.ritsumei.ac.jp/acd/re/k-rsc/hss/book/pdf/vol06_07.pdf.

27.Suruhanjaya Hak Asasi Manusia Malaysia (SUHAKAM). (2013). Laporan Inkuiri Nasional Mengenai Hak Tanah Orang Asal/Asli. Kuala Lumpur: Suruhanjaya Hak Asasi Manusia Malaysia (SUHAKAM).

28. United Nations Development Programme (UNDP). (2012). Indigenous voices in Asia-Pacific: Indentifying the information and communication needs of indigenous peoples.

29.Yusof, Y., Roddin, R., \& Warman, S. (2017). Pembangunan Profil Standard Kebangsaan Bagi Kemahiran Informal Orang Asli Malaysia Demi Kelestarian Warisan Etnik (The Development of National Informal Competency Standard, 1(2), 190-202. 